\title{
Trauma journalism and disaster resilience. German journalists' coping strategies when reporting about crime, violence, accidents, crises and natural disasters
}

\author{
Melanie Verhovnik, Katholische Universität Eichstätt-Ingolstadt, Sprach- und \\ Literaturwissenschaftliche Fakultät \\ melanie.verhovnik@ku.de
}

\begin{abstract}
Accidents, violent crimes, war and natural disasters are traumatic experiences for individuals directly and indirectly involved, and often result in long-lasting consequences which are difficult to deal with. Journalists who report on these incidents are part of this group. Since the events on 9/11, this topic has shifted into the public's focus, but there is still little known about the effects of crisis coverage for the journalists involved. The results of 30 semi-structured interviews show a dependence on coping strategies for the specific job situation, and a dependence on third variables, such as age and individual resources.
\end{abstract}

Keywords

coping strategies, crime, disaster, journalist, resilience, trauma journalism

\section{Theoretical background}

A person directly or indirectly confronted with a catastrophe, traffic accident, violent crime, war or natural disaster has to deal with the physical and psychological effects of these events. Such traumatic experiences often lead not only to visible somatic consequences, but also to psychological injuries, which could result from feeling that one's life is at risk, loss of control and perceived helplessness. The spectrum ranges from mild to severe mental health problems, such as disturbing thoughts, feelings, or dreams related to the event, persistent fears, difficulties concentrating, nervousness, flashbacks and more (e.g., Allen , 2001; Rosen, 2004; Scaer, 2005; 2001). Media plays a decisive role in this process because media coverage on the mentioned incidents can be an additional burden for the victims (e.g., Bernstein et al., 2007; Cantor, 2002; Cohen, 1997; McFarlane, 1986; Murphy, 1984). The connection between media coverage and (re)trauma has been researched well (e.g., Cohen et al., 2013; Duarte et al., 2011; Haravuori et al., 2011; Mikhail, 2001; Muller, 2010; Neria \& Sullivan, 2011; Vasterman et al.,
2005; Wilms, 2007), although longitudinal studies are still rare and thus required (e.g. Putnam, 2002; Vasterman et al., 2005).

Furthermore, the effects of media coverage are still measureable if someone is not directly (e.g., as victim) or indirectly (e.g., as relatives) affected by a trauma-related incident. Reception of media coverage on dramatic incidents is known to leads to (massive) stress reactions. In 1995, the Oklahoma City bombing led to 168 deaths and over 700 injured victims. The intense media coverage and its reception led to symptoms of post-traumatic stress disorder among school children. The children whose TV consumption in the seven weeks after the bombings was "most" or "all" related to the attacks, reported more symptoms than the children whose TV consumption was less related to the attacks, regardless of whether the children lost a close family relative in the bombings (Pfefferbaum et al., 1999a; Pfefferbaum et al., 1999b).

Other studies show, for example, increased anxiety after reception of media coverage on terrorism and political violence (Sloan, 2000), increased substantial stress reactions after reception of me- 
dia coverage on 9/11 (Ahern et al., 2002; Schuster et al., 2001), and increased symptoms of post-traumatic stress disorder after media coverage on violence and death due to the Gulf War (Cantor et al., 1993; Nader et al., 1993). Aside from the negative effects of media coverage on traumatic incidents, this kind of reporting can also have positive effects: the media provides information and this could be helpful in traumatic situations; further media coverage might provide helpful tips on services for victims and relatives (e.g., Kira et al., 2008).

The impact of disaster coverage on relevant actors - the journalists - is little explored. However, effects can be expected, since journalists do not only experience media coverage, they produce it and are therefore part of the equation. As the Dart Center for Journalism und Trauma states, "reporting responsibly and credibly on violence or traumatic events - on street crime and family violence, natural disasters and accidents, war and genocide - is a great challenge" (Dart Center Ochberg Fellowship Guidelines, 2015; see further Backholm \& Idås, 2016).

Case studies from different countries (e.g., Backholm \& Idås, 2015; Backholm \& Björkqvist, 2012a; Bull \& Erman, 2002; Evans, 2003; Lund, \& Olsson, 2015; Massé, 2009; Massé, 2011; Massé et al., 2013; McMahon, 2001; Van der Merwe, 2005; in summary Smith, Newman, \& Drevo, 2015) point out that reporting on catastrophes and disasters can be very onerous for journalists. As "first responders," journalists are usually on the scene quickly. They feel pressure to not only bring back a good story, but also to deliver pictures and video footage which is as exclusive as possible, as detailed as possible and as close as possible to the scene. New phenomena, such as school shootings, which have occurred more frequently since the 90's, raise the pressure of fast and even live coverage which develops momentum during the incident. An explorative study of the reaction of journalists who report from the scene (Columbine, 1999; Jokela, 2007; Kauhajoki, 2008) shows the high level of post-traumatic stress in journalists who are exposed and clearly shows (with help of interview statements) the multiple breach of rules which often follows school shootings (see Backholm et al., 2012, p. 148-155; Backholm \& Björkqvist, 2012b).

Journalism is a profession with free access - there is neither a universal standard of education, nor mandatory rules for editorial departments on how to report on crimes, accidents and other such incidents. Guidelines, voluntary agreements or institutions (for example the German Press Council in Germany) offer an orientation, but do not include possible sanctions. How journalists should behave and how they can protect themselves from physical and psychological effects is often left up to them. The Dart Center for Journalism and Trauma, a project of the Columbia University Graduate School of Journalism, is dedicated to informed, innovative and ethical news reporting on violence, conflict and tragedy (www.dartcenter.org). In addition to their Center in North America, The Dart Center also has a Center for Europe and Asia Pacific, e.g., in Germany. Their efforts to inform the public about the psychological and physical impact of coverage on journalists and to initiate scientific projects and workshops for journalists are very important steps (e.g., Hight, 2009). Similarly, The Institute for War and Peace Reporting (www.iwpr. net) which supports reporters and journalists in countries in conflict and crisis, The International Society for Traumatic Stress Studies (www.istss.org) that promotes advancement and exchange of knowledge about traumatic stress, The Committee to Protect Journalists (www.cpj.org) and the International News Safety Institute (www. newssafety.com) that are dedicated to journalists' safety, raise awareness of stress and trauma issues and that help to train media personnel in conflict zones, are all important resources.

So far, there is still a lack of basic empirical research showing the problems and risks for journalists regarding coverage of crisis, war and catastrophe, how journalists cope with death, harm and despair (which, of course, they experience), to what extent they are affected, which strat- 
egies they have developed to deal with these difficulties, or if the editorial departments they are working for offer help. Although numerous accounts of autobiographical and biographical studies of journalists who have covered traumatic events exist, systematic analyses of the emotional consequences of reporters covering acts of violence are rare.

A relevant factor in the management of crises and traumatic experiences is resilience. It is commonly defined as the "ability to deal with crisis and to take them as a chance for personal development" (Elder, 1998; Masten \& Coatsworth, 1998). The American Psychological Association (2010) defines resilience as "the process of adapting well in the face of adversity, trauma, tragedy, threats or even significant resources of threat." Resilience is "a trait that people either have or do not have and being resilient doesn't mean that a person doesn't feel emotional pain or sadness, or that a person isn't confronted with difficulty or distress" (American Psychological Association, 2010). Resilience "involves behaviors, thoughts and actions that can be learned and developed in anyone" (American Psychological Association, 2010). The term "resilience" is not only used in the context of coping with extreme situations, but also, for example, for the ability of an individual to properly deal with burdens in their work life. Especially informative are additional variables, for example the age of the journalist, work routine and how often they are confronted with tragic experiences. Here, both protection and risk factors may arise.

\section{Research questions and methodological approach}

The following study takes a qualitative approach. Although international case studies provide some theses on this topic, there is a lack of concrete research on how the results apply to Germany. Moreover, there is also a lack of research on whether coping strategies apply beyond all media borders, independent of media areas, such as TV or print, and independent of single incidents. As a group of "players" in disaster reporting, journalists are highly relevant for a number of reasons. First of all, disaster coverage is often criticized with regard to ethical aspects. Journalists in the modern media world feel pressure as competition rises and traditional media loses recipients. Secondly, it cannot be expected that individuals alone maintain ethical standards in media coverage, but editorial departments must offer further training to their staff. If possible, there should be stricter guidelines in the editorial department to which journalists can adhere. Thirdly, the current situation for journalists in Germany is unclear. Case studies from other countries indicate that coverage of disasters leads to a high level of psychological stress, that the ability of coping with this (resilience) depends on other variables, for example age, and that the responsibility for this kind of coverage attributes individually and not institutionally, so that there is commonly no help from the editorial departments. Fourthly, journalists who showed high resilience are extremely relevant, as this study aims to successfully identity strategies for successfully coping with stressful coverage.

Those thoughts lead to the following research questions:

, RQ1: How do journalists experience a crisis situation; which problems and difficulties in general can be identified?

, RQ2: Which special forms of psychological and physical burdens can be identified and did journalists develop strategies which helped them?

, RQ3: Can criteria be identified which benefit individual resilience, for example support through the editorial department?

, RQ4: Does reporting about crisis affect attitudes, opinions and behavior of journalists - concerning this form of media coverage?

To answer the research questions, 30 interviews took place between December 2013 and December 2014 with journalists from all fields with a focus on print and TV media. The interviews lasted between 25 and 
85 minutes. The first round of interviews was done with journalists who work for major German media, national newspapers and TV stations. As a second step, other media (radio and online) was included and domestic journalists were interviewed as well as journalists who worked abroad. A necessary condition for including a journalist in the sample was that he or she either reported on a special incident (e.g. a school shooting), or was in the editorial

Table 1: Distribution of interviewed journalists related to age and $\operatorname{sex}(n=30)$

\begin{tabular}{l|ccr}
\hline Sex & \multicolumn{3}{|c}{ Age } \\
& Under 30 years & 31 to 50 years & Over 50 years \\
\hline Women & 2 & 1 & 2 \\
Men & 5 & 9 & 11 \\
\hline
\end{tabular}

Table 2: Distribution of interviewed journalists related to media area and sex $(\mathrm{n}=30)$

\begin{tabular}{l|cccccr}
\hline Sex & \multicolumn{7}{|c}{ Media area } \\
& Print & TV & Online & Radio & $\begin{array}{l}\text { News } \\
\text { agency }\end{array}$ & $\begin{array}{r}\text { Photo- } \\
\text { graphy }\end{array}$ \\
\hline Women & 2 & - & 2 & 1 & - & - \\
Men & 8 & 9 & 4 & 1 & 1 & 2 \\
\hline
\end{tabular}

Table 3: Distribution of interviewed journalists related to working situation and $\operatorname{sex}(n=30)$

\begin{tabular}{l|ccr}
\hline Sex & \multicolumn{3}{|c}{ Working situation } \\
Freelancer & $\begin{array}{l}\text { Permanent } \\
\text { employee in } \\
\text { managerial } \\
\text { position }\end{array}$ & $\begin{array}{r}\text { Permanent } \\
\text { employee in } \\
\text { non-manage- } \\
\text { rial position }\end{array}$ \\
\hline Women & 1 & - & 4 \\
Men & 10 & 6 & 9 \\
\hline
\end{tabular}

department responsible for traumatic occurrances like traffic accidents. All journalists approached were willing to take part in this study, indicating their interest in discussing the issue, and journalists included experienced the incidents/disasters themselves and were personally at the scene. To protect all participating journalists, they remained anonymous. Not all of the journalists felt this was necessary, but most of them feared that criticism of the way editorial departments deal with their employees might lead to disadvantages in the journalist's work. The guidelines were adapted for the key aspects of the interview (for example, coverage on catastrophes, accidents or crimes, such as school shootings). School shootings are overrepresented in the sample as cause for coverage. The guidelines asked about the number of incidents that journalists reported memories and images in their minds, about what the individual reporting on the crises and disasters looked like (and if former incidents played a role in this reporting, what the contact with victims and/or relatives looked like, etc.), which problems the journalists were confronted by at the scene and in the aftermath, what the collaboration with the editorial department looked like, what individual feelings and thoughts the journalists had, if they were prepared for those incidents and which consequences resulted from their reporting - for themselves and for their work. The interviews were transcribed and analyzed by computer. The first results were presented at the NordMedia Conference in August 2015 in the section "Environment, Science and Risk Communication" (Verhovnik, 2015). The journalists were interviewed in German, and the statements referred to in this paper were translated into

Table 4: Distribution of interviewed journalists related to type of incident and sex ( $n=41$, multiple answers)

\begin{tabular}{l|ccrr}
\hline Sex & \multicolumn{3}{|c}{ Type of incident } & \multicolumn{2}{c}{$\begin{array}{l}\text { Reporting on major incidents } \\
\text { (school shootings, rampage, } \\
\text { flood, etc.) }\end{array}$} & $\begin{array}{l}\text { Police and court } \\
\text { reporting (regularly) }\end{array}$ & War reporting & $\begin{array}{r}\text { Reporting from crisis regions } \\
\text { (regions shaped by poverty and } \\
\text { high criminal rates) }\end{array}$ \\
\hline Women & 7 & 3 & - & - \\
Men & 19 & 8 & 2 & 2 \\
\hline
\end{tabular}


English by the author. Tables 1-4 show the distribution of the interviewed journalists related to age, sex, media area, working situation and incident type.

\section{Results}

As previously mentioned, the journalists were very interested in the study. As will be seen later, this seems to stem from the fact that journalists reporting on crises, disasters and crime primarily work alone. The main results are presented by answering the research questions as follows:

, RQ 1: How do journalists experience a crisis situation; which problems and difficulties in general can be identified?

The questioned journalists reported "exclusively" to "occasionally" on crises and catastrophes. This ranged from traffic accidents, serious crimes, such as school shootings to natural disasters, and reporting from war scenes and areas of conflict (e.g., reporting from slums in Brazil, or from the Iraq war). It is either the journalists' main occupation or they are sent out because the editorial department is understaffed or he/she is simply on duty.

I have been a police reporter for ten years. Every year there has been approximately 60 victims - from homicide to suicide and traffic accidents. One time a man disappeared in an 80-meter deep drill hole. I have seen everything you can think of. I have seen people in every state and shape: as a stain on the highway, single body parts or completely burnt. (I12_15, freelance journalist for public service broadcasting)

I was in the Ukraine (Majdan) after many people had been shot. You have a constant feeling of fear and find yourself in a situation you have never experienced anywhere in Germany. (I8_5, journalist at a magazine)

I have been to normal events which just escalated at some point, for example a demonstration where a police operation and the use of water cannons were necessary. There were flying stones and bottles. I remember the G8 conference in Heiligendamm a few years ago when it came to an excess of violence. (I13_6, freelance photographer)

The journalists report severe experiences at the sites. Very often they have the impression they are not able to cope with the situation themselves: "Generally I am the first contact person for someone who would rather need a counselor or an expert with the professional background for situations like this. I'm often helpless and can't think of anything to say to those people" (I7_54, journalist at a regional newspaper). Apparently legal insecurities regarding their own professional work play a big role - what are journalists allowed to do and what is illegal? "I was just standing there. I didn't even have an idea about what I was allowed to do, for example: Am I allowed to take pictures? I talked to the police to discuss what I was allowed to do. I was dreaming about it for two nights because it was so difficult - the firefighters had been looking for something and at some point somebody asked them what they were actually looking for. They responded that they are looking for the leg. They couldn't find it; it just wasn't there anymore" (I7_27, journalist at a regional newspaper).

There are various problems on location. Of course problems arise which reporters commonly experience, for example difficulties getting close enough to the scene, problems such as extreme weather, insufficient funds (for example on a mission abroad), and time pressure. "It sounds ridiculous but your first thoughts are: What if this takes the whole night? Is my jacket warm enough? Where can I sit down for a few minutes? Where can we get dinner? Will my cameraman get through this?" (I11_12, journalist at a regional private TV station). "Where can I get money on a public holiday? The administration of public service broadcasting is not designed for this. They don't have a safe somewhere with 10000 Euros which you can access in case of emergencies" (I17_28, journalist for public service broadcasting). Specific problems are, however, confrontation 
with relatives, risk of their own life due to confrontations with perpetrators, toxic substances, etc. "Of course I realize that I have put myself in danger during those incidents - but mostly when everything was over already. Many times I risk a lot, push further and don't listen to firefighters or police officers. But that is in the nature of a journalist. If you want to find out what happened, you would go anywhere to get as close as possible" (I12_48, freelance journalist for public service broadcasting). "The response the media gets from the victim's relatives has changed. I often notice that when I am at the scene of an accident and there are family members around. It has happened to me before that they were upset about me being there" (I7_52, journalist at a regional newspaper).

, RQ2: Which special forms of psychological and physical burdens can be identified and did journalists develop strategies which helped them?

The question for psychological and physical burdens shows two clear tendencies. The first is that in the samples, psychological problems usually occur after the coverage and are, in total, more frequent than physical effects. Secondly, psychological problems occur on a higher spectrum than physical effects. In the sample, flashbacks, dreams or nightmares, a nervous condition, unspecific illness, grief, sorrow, and excessive demands were found. Physical problems occur, for example, as an immediate threat to life, sickness, headaches and bruises. The following statements from the interviews illustrate these results:

It was on my mind for a very long time afterwards. I was thinking about it a lot. I have to admit that I was upset for days. (I2_58/59, journalist for public service broadcasting)

No, you never really get used to it. Unfortunately, you become numb to it - that is true. A normal homicide doesn't really bother me anymore but when you get into details and you have an idea of how it all happened - that is upsetting. On those days you go home and look under your bed because you become a scared little child again. (I18_9/10; news agency)

Sometimes I had flashbacks. When I saw a certain color that reminded me of the color of a vehicle that was involved in an accident, I had flashbacks. The accident became vivid again. But I talked to my psychologist about it because you can't really tell anyone at home what you just saw. (I12_58, freelance journalist for public service broadcasting)

I had spent some time in Kosovo and there you get used to necessary patterns. When you get out of a car, never step on grass. Always stop the car on concrete or tar and never step out on an earth road. A mine could be buried there. A mine can't be buried in tar. And when you come back home you still avoid the median on the streets after four weeks, because you haven't realized that you're back. (I17_43, journalist for public service broadcasting)

I had bruises all over my arm and my eyes were red and I had a terrible headache. But I had to go back to the editorial office because the story had to be finished the next day. (I15_23; public service broadcasting)

The psychological and physical problems lead to the coping strategies that journalists use, and central tendencies can be identified. Journalists turn to simple strategies which have proven helpful. For example, they keep a certain distance to scenes of accidents in order to not see all of it: "I think you get numb after a while and you don't let it get to you. You can also just keep your distance, because you know exactly when somebody is getting cut out of a car and you just back up a few more meters. I don't want to see this. You know what you would see and you don't want to experience that again" (I7_42, journalist at a regional newspaper). At the same time they try to establish an inner distance and keep their distance. Concentrating on professional work often helps. Many journalists feel supported and strengthened when they talk about what they have experienced with coworkers or family. Occasionally professional help is engaged. 
"You have to imagine that: We went with boats through a small town afterwards and the water level reached traffic signs. There were dead animals in the water everywhere. Whole oil tanks were loose and in the water. The smell was terrible and you won't get rid of it again. It sticks in your nose and I have to admit that this is drastic. It stays in your mind and you have to talk about it afterwards, with coworkers, your family or wife. You have to talk about it to cope with it" (I18_7, news agency). "You can't allow yourself to break down on location. As a professional journalist you have the required distance. I received psychological help. Without that it is impossible and you will get sick at some point. After ten years I stopped with coverage like that" (I12_22/23, freelance journalist for public service broadcasting). To ask experienced colleagues is an obvious and proven strategy: "My strategy was to stick to my cameraman as he had been in the Middle East a lot and knows where to stand and not get shot" (I15_39, journalist for public service broadcasting). It does, however, become problematic when there is nobody that can be asked. The younger the journalists are and the more often they work as a freelancer and/or for local media, the more often they are left alone, usually already at the time of their first crisis incident. The interviewed journalists thereby agree that such strategies are, on the one hand, daily routines that are developed with increasing job experience, but that for reporting on disasters, crisis and crime, individual coping strategies are needed: "If you have been through this already a few times, you have had certain experiences. You know then how to handle this the next time and I think it makes you stronger" (I9_10, journalist at a local newspaper). At this point it is clear that not every strategy is suitable for any journalist. In particular, although a few journalists stated that talking about their experiences helps a lot, this is not the case for all interviewees.

, RQ3: Can criteria be identified which benefits individual resilience, for example, support through the editorial department?
Resilience is an ability to deal with problems during one's lifetime in a constructive way. The study searched for factors that support situational conditions and therefore could influence resilience as "moderating variables." The interviews clearly show that "age" and "experience" are personal factors, and that "experienced colleagues" and "support through the editorial department" are structural factors that moderate resilience. "I think what I learned from my cameraman and the other journalists that had been there was: No matter what, you have to try to stay calm. Sometimes I was too shocked myself and because of that I wasn't able to conduct an interview critically" (I15_56, journalist for public broadcasting). As the interviews showed, many of the editorial departments do not show consideration for those with less experience. "Five people work at my local editorial office and it is a standard duty for me to report on accidents. At 28, I am the youngest reporter and that is why I'm the first pick to be sent out on location" (I7_11, journalist at a regional newspaper). Journalists who get the chance to learn from experienced coworkers are lucky. Those who do not have this opportunity have to go on location anyways. This especially applies to freelancers. "You have to experience that a few times. When a coworker goes on location, then I accompany him/her and watch. But most of the time you just get an office cell phone and if something happens you have to go. And in the end you are all by yourself at the scene of an accident with five victims or a homicide" (I11_16, journalist at a regional private TV station). "They were happy that as a freelancer I did those jobs. If the employees go on location, the editorial department has to provide psychological help afterwards. As a freelancer you do not have protection like that, the networks do not care. If you are lucky you can talk to a minister on location" (I12_33_34, freelance journalist for public service broadcasting).

Furthermore, the analysis of the interviews showed that standardized education does not exist and that journalists that report about disasters are only pre- 
pared by their editorial departments if this kind of reporting is their main job. "What I learned at university didn't help me at all. Rather, I think it is something you either have or you don't. Who you are and who you might not be. My studies for a fact didn't help me at all in situations like that" (I10_8, freelance photographer). Changes seem to happen after big tragedies, when editorial departments are encouraged to reflect. In the sample, this was the case after a school shooting and a big flood: "We changed certain structures at our network afterwards. We worked out an emergency plan if something like that happens again" (I11_18, journalist at a regional private TV station). Journalists who mainly handle crises would like to have a constant contact person in the office, who can help with problems and difficulties. "When you drive out there you should be prepared psychologically and structurally. You have to be aware of the fact that you might see things you have never seen before. You should have a contact person in the office who is always available, day and night, for example when there is a big crisis" (I8_3, journalist at a magazine). When there is no support available, journalists usually act pragmatically and try to avoid stressful situations. "The main difficulty is to bring you to talk to the concerned person. Even if you have been a journalist for a long time it is still a major challenge to talk to traumatized people and relatives of the victims. I tend to avoid those situations and only do it if the editorial department specifically asks for it” (I29_36, journalist at a interregional newspaper).

, RQ4: Does reporting about crisis affect attitudes, opinions and behavior of the journalists - concerning this form of media coverage?

The confrontation with victims or relatives led to increased reflection by interviewed journalists on their work and behavior. Also, reflection as a team, especially after bigger, unusual incidents (as opposed to e.g., traffic accidents), led to subsequent corrections in the assessment of the coverage: "If I could do it again, I would relativ- ize statements more. In retrospect I know now how incredibly chaotic the situation was, and how little the police actually knew" (I1_55/58, journalist for public service broadcasting). For many journalists it was only obvious in retrospect that the extent of the incident they were confronted with was that severe. "It is difficult to prepare for this, because I was incredibly surprised by the dimension of this flood. You don't expect such bad things - you don't expect swimming dead dogs, cows and horses" (I18_17, news agency). The question of possible consequences leads to reflections about their own education. "When I arrived at the scene of an accident I had asked myself many times how I would react as a first responder. I was also thinking that I should renew my first aid skills" (I7_48, journalist at a regional newspaper). Others report changes concerning interviewing persons that are involved in the incident:

I learnt for sure that you should take your time. Take your time to listen, because this was extremely important while talking to the relatives. But also time for authorizing of these talks, so that nothing happens under pressure and that the relatives and survivors have time to read everything calmly. (I23_28; journalist at a magazine)

I became more thoughtful. I still read my articles and listen to my own stuff. I still have contact with a few relatives. They are still suffering and also as a journalist, you are still affected. I realized that I became more reserved in dealing with victims or their relatives. (I28_19, journalist at a interregional newspaper)

That media coverage was really traumatic for the relatives who had previously lost their daughter - I was not really conscious about that. I thought this is normal reporting about a daily event, just as you report about something dramatically. (I6_801, journalist at a interregional, weekly newspaper) 


\section{Conclusions and limitations of the study}

In the following section, central tendencies are summarized and limitations of the study, as well as possible further research are discussed. Firstly, the interviews showed a strong interest on the part of the journalists for this topic. The topic is not only important for journalists, but nevertheless is rarely reported on. The following tendencies should be analyzed in further quantitative and representative surveys:

1. The more unspecific the coverage of the crisis (e.g., "normal" local journalist that report about severe traffic accidents vs. professional war reporter), the more insufficient the education and counseling of the journalist.

2. The younger and more inexperienced the journalist, the stronger the psychological impact.

3. The younger and more inexperienced the journalist, the more frequently they did not have any strategies or way of handling victims or relatives. This affects psychological impacts in a negative way.

4. Professional handling of the psychological and physical impacts is very rare. More often, journalists use simple strategies that they adopt themselves and which they have experienced as helpful.

5. Journalists have no expectations that professional counseling/support will be available during education or work.

6. Positive experiences in association with victims or relatives generally leads to more safety in crisis coverage. Empathy might play a moderating role.

7. Negative experiences in association with victims or relatives or negative crisis reporting leads to increased reflection on the coverage and increased reflection in the editorial departments. Editorial departments still lag behind in establishing professional standards.

8. Psychological burdens increase with the frequency of crisis reporting. At the same time, this trend is growing. "Professional" crisis reporters are exposed to many burdens, but they also have the best counseling and strategies for coping with them.

The presented results are consistent with previous (case) studies related to the psychological and physical burdens that journalists covering disasters and crisis are confronted with. In a further quantitative and representative survey, the use of a Checklist to Posttraumatic Stress Disorder or Reaction Index (Steinberg et al., 2004) is recommended. Due to the fact that there is no professional register for full-time and freelance journalists in Germany, representativity could be reached as far as possible by using registers of journalists' associations as was done in earlier studies. Analysis has shown that the factor "empathy" might play a decisive role. While empathy is of course absolutely relevant in the daily work of journalists, this relevance might even increase with reporting about crime, crisis and disasters, which was also shown in the statements regarding experiences with victims and relatives. It is therefore recommendable to control empathy as a factor in a quantitative survey. The results also show that direct experiences with victims and relatives often lead to changes in opinions and attitudes and subsequently to changes in reporting, as well as a greater awareness of media ethical requirements.

Although the interviewed journalists were carefully selected, men are clearly overrepresented. At the same time the media sectors "radio" and "photography" are clearly underrepresented; additionally, there was only one person in the sample who worked for a news agency. The cited statements are therefore not representative and find their limits in the qualitative approach and the selected sample. Most of the interviewed journalists were worried about possible consequences for critically pointing out deficits concerning crisis, crime and disaster coverage in the editorial departments, if they were cited with their real names or were identifiable due to overly detailed social statistical information. Therefore we avoided giving more detailed statistical information due to the fact that in Germany, especially in 
the big public service broadcasting organizations, some journalists have very clear professional roles and an identification of single participants in this study could not be entirely excluded. In a more extensive, representative survey this data (e.g. also work experience) should be collected.

At the same time, the statements provide important information on trends and tendencies in the coverage of crises, disasters and crime, and provide clear indications for psychological and physical burdens to which journalists are exposed. Additionally, the study clearly shows that professionalism in crisis reporting is rare and only applies to journalists who mainly work in that field. Many journalists included in this study work, for example, for local newspapers or TV stations, where reporting on disasters is only one activity among many. There is a need for improved training of the journalists and support through the editorial departments.

\section{Acknowledgements}

This research did not receive any specific grant from funding agencies in the public, commercial, or not-for-profit sectors. I thank Petra Hemmelmann and the students of the masters' classes in 2013/14 and 2014/15 for support in conducting the interviews.

\section{References}

Ahern, J., Galea, S., Resnick, H., Kilpatrick, D., Bucuvalas, M., Gold, J., \& Vlahov, D. (2002). Television images and psychological symptoms after the September 11 terrorist attacks. Psychiatry, 65(4), 289-300.

Allen, J. G. (2001). Traumatic Relationships and Serious Mental Disorders. Chichester: Wiley.

American Psychological Association. (2010). The road to resilience. http://www.apa. org/helpcenter/road-resilience.aspx. Accessed 8/3/2016.

Backholm, K., \& Trond, I. (2016). Ethical Dilemmas, Guilt and Posttraumatic Stress in News Journalists. In U. Carlsson (Eds.),
Freedom of Expression and Media in Transition. Studies and Reflections in the Digital Age (191-197). Gothenburg: Nordicom.

Backholm, K., \& Trond, I. (2015). Ethical dilemmas, work-related guilt, and posttraumatic stress reactions of news journalists covering the terror attack in Norway in 2011. Journal of Traumatic Stress, 28(2), 142-148.

Backholm, K., Moritz, M., \& Björkqvist, K. (2012). U.S. and Finnish journalists: a comparative study of roles, responsibilities, and emotional reactions to school shootings. In G.W. Muschert, \& J. Sumiala (Eds.), School Shootings: Mediatized Violence in a Global Age (141-160). Bingley: Howard House.

Backholm, K., \& Björkqvist, K. (2012a). The mediating effect of depression between exposure to potentially traumatic events and PTSD in news journalists. European Journal of Psychotraumatology, 3, 18388. http://dx.doi.org/10.3402/ejpt.v3i0.18388. Accessed 8/3/2016.

Backholm, K., \& Björkqvist, K. (2012b). Journalists' emotional reactions after working with the Jokela school shooting incident. Media, War \& Conflict, 5(2), 175-190.

Bernstein, K.T., Ahern, J., Tracy, M., Boscarino, J.A., Vlahov, D., \& Galea, S. (2007). Television watching and the risk of incident probable posttraumatic stress disorder: A prospective evaluation. Journal of Nervous and Mental Disease, 195(1), 41-47.

Bull, C., \& Sam, E. (2002). At Ground Zero: 25 stories from young reporters who were there. New York: Thunder's Mouth Press.

Cantor, J. (2002). Fright reactions to mass media. In B. Jennings, \& D. Zillmann (Eds.), Media effects: Advances in theory and research (287-306). Mahwah, NJ: Erlbaum.

Cantor, J., Mares, M.-L., \& Oliver, M. B. (1993). Parents' and children's emotional reactions to televised coverage of the Gulf War. In B. Greenberg, \&W. Gantz (Eds.), Desert Storm and the mass media (325-340). Cresskill, NJ: Hampton Press.

Cohen, N. (1997). Lessons learned from providing disaster counseling after TWA flight 800. Psychiatric Services, 48(4), 461-462.

Dart Center Ochberg Fellowship Guidelines. (2015). Ochberg Fellowship Guidelines. http://dartcenter.org/ochberg-fellowship-guidelines. Accessed 8/3/2016. 
Duarte, C. S., Wu, P., Cheung, A., Mandell, D., Fan, B., Wicks, J., Musa, G., \& Hoven, C.W. (2011). Media use by children and adolescents from New York City 6 months after the WTC attack. Journal of Traumatic Stress, 24(5), 553-556.

Elder, G.H. Jr. (1998). The life course as developmental theory. Child Development, 69(1), 1-12.

Evans, H. (2003). War stories: Reporting in the time of conflict. Charlestown, MA: Bunker Hill Publishing.

Haravuori, H., Suomalainen, L., Berg, N., Kiviruusu, O., \& Marttunen, M. (2011). Effects of media exposure on adolescents traumatized in a school shooting. Journal of Traumatic Stress, 24(1), 70-77.

Hight, J., \& Smyth, F. (2004). Tragedies \& journalists. http://dartcenter.org/content/tragedies-journalists-6. Accessed 8/3/2016

Holman, A.E., Garfin, D. R., \& Cohen Silver, R. (2013). Media's role in broadcasting acute stress following the Boston Marathon bombings. PNAS, 111(1), 93-98.

Kira, I. A., Templin, T., Lewandowski, L., Ramaswamy, V., Ozkan, B., \& Mohanesh, J. (2008). The physical and mental health effects of Iraq War media exposure on Iraqi refugees. Journal of Muslim Mental Health, 3(2), 193-215.

Lund, M. K., \& Olsson, E.-K. (2016). When routines are not enough. Journalists' crisis management during the 22/7 domestic terror attack in Norway. Journalism Practice, 10(3), 358-372.

Massé, M.H., Popovich, M. N., \& Kinsey, D. F. (2013). An Examination of Journalist Perceptions toward Covering Tragedy and Trauma. Operant Subjectivity, 36(3), 165-178.

Massé, M.H. (2011). Trauma journalism: On deadline in harm's way. New York: Continuum International Publishing Group.

Massé, M.H. (2009). On deadline in harm's way: A qualitative study of trauma journalists. Paper presented at Association for Education in Journalism and Mass Communication Annual Conference, August 5-8, Boston, MA.

Masten, A. S., \& Coatsworth, D. J. (1998). The development of competence in favorable environments. Lessons from research on successful children. American Psychologist, 53(2), 205-220.

Mayring, P. (2010). Qualitative Inhaltsanalyse. Grundlagen und Techniken. Weinheim: Beltz.

McFarlane, A. (1986). Victims of trauma and the news media. Medical Journal of Australia, 145(11-12), 664.

McMahon, C. (2001). Covering Disaster: A Pilot Study into Secondary Trauma for Print Media Journalists Reporting on Disaster. The Australian Journal of Emergency Management, 16(2), 52-56.

Mikhail, J. (2001). The Media and the Trauma Service: Part I - Friend or Foe? Journal of trauma nursing: the official journal of the Society of Trauma Nurses, 8(3), 73-74.

Muller, D. (2010). Ethics and trauma: lessons from media coverage of Black Saturday. Australian Journal of Rural Health, 18(1), 5-10.

Murphy, S. (1984). After Mount St. Helens. Disaster stress research. Journal of Psychosocial Nursing, 22(7), 9-18.

Neria, Y., \& Sullivan, G. M. (2011). Understanding the mental health effects of indirect exposure to mass trauma through the media. The Journal of the American Medical Association, 306(12), 1374-1375.

Nader, K., Pynoos, R., Fairbanks, L. A., Al-Ajeel, M., \& Abdulrahman A.-A. (1993). A preliminary study of PTSD and grief among the children of Kuwait following the Gulf crisis. British Journal of Clinical Psychology, 32(4), 407-416.

Pfefferbaum, B., Moore, V.L., McDonald, N. B., Maynard, B.T., Gurwitch, R.H., \& Nixon, S. (1999a). The role of exposure in posttraumatic stress in youths following the 1995 bombing. Journal of the State Medical Association, 92(4), 164-167.

Pfefferbaum, B., Nixon, S., Tucker, P., Tivis, R. D., Moore, V.L., Gurwitch, R. H., Pynoos, R. S., \& Geis, H.K. (1999b). Posttraumatic stress response in bereaved children after the Oklahoma City bombing. Journal of the American Academy of Child and Adolescent Psychiatry, 38(11), 1372-1379.

Putnam, F.W. (2002). Televised trauma and viewer PTSD: Implications for prevention. Psychiatry, 65(4), 310-312.

Rosen, G. (2004). Posttraumatic Stress Disorder: Issues and Controversies. Chichester: Wiley. 
Scaer, R. (2005). The Trauma Spectrum: Hidden

Wounds and Human Resiliency. New York, London: W.W. Norton \& Company.

Scaer, R. (2001). The Body Bears the Burden: Trauma, Dissociation, and Disease. Binghamton: The Haworth Medical Press.

Schuster, M.A., Stein, B. D., Jaycox, L. H., Collins, R.L., Marshall, G. N., Elliott, M. N., Zhou, A.J., Kanouse, D. E, Morrison, J.L., \& Berry, S. H. (2001). A National Survey of stress reactions after the September 11, 2001 terrorist attacks. New England Journal Medicine, 345(20), 1507-1512.

Silver, R. C., Holman, A. E., Andersen, J.P., Poulin, M., McIntosh, D. N., \& Gil-Rivas, V. (2013). Mental- and physical-health effects of acute exposure to media images of the September 11, 2001, attacks and the Iraq War. Psychological Science, 24(9), 1623-1634.

Slone, M. (2000). Response to media coverage of terrorism. Journal of Conflict Resolution, 44(4), 508-522.

Smith, R., Newman, E., \& Drevo, S. (2015). Covering Trauma: Impact on Journalists. http://dartcenter.org/content/covering-trauma-impact-on-journalists. Accessed 8/3/2016.

Steinberg, A. M., Brymer, M. J., Decker, K. B., \& Pynoos, R. S. (2004). The University of California at Los Angeles Post-traumatic Stress Disorder Reaction Index. Current Psychiatry Reports, 6, 96-100.

Van der Merwe, M. (2005). Trauma and journalism: Commentary on the narrative trauma account of one journalist. Ecquid Novi: African Journalism Studies, 26(1), 128-131.

Vasterman, P., Yzermans, C. J., \& Dirkzwager, A. J.E. (2005). The role of the media and media hypes in the aftermath of disasters. Epidemiologic Reviews, 27(1), 107-114.

Verhovnik, M. (2015). Disaster resilience. Journalists' coping with reporting about crime, violence, accidents, crisis and natural disasters. Paper presented at NordMedia Conference, 13.-15. August, University of Copenhagen, Denmark.

Wilms, I.A. (2007). "The shots after the shots" or the media trauma of Erfurt. Psychotherapie Forum, 15(4), 179-182. 